\title{
IMPLICATION OF UNPLANNED URBANIZATION ON RIVER BASINS IN SRI LANKA WITH REFERENCE TO THE UPPER MAHAWELI CATCHMENT AREA
}

\author{
JMS Jayawerra \\ National Building Research Organization, Colombo 05
}

Sri Lanka has a total land area of $65,525 \mathrm{sq} . \mathrm{km}$ and a population of around 19 million. The land man ratio of the country was 0.34 ha per person in 2000. The central highland rises to about $2500 \mathrm{~m}$ above mean sea level, which counts about $25 \%$ of the land area of the country. Landform range varies from flat to very steep terrain from mean sea level. The rivers that radiate from the central hills provide a large hydropower potential and also permit a variety of products in agriculture. This network of rivers contribute to the economy in varies of ways. Among them the water for the agricultural sector and the hydropower for the energy sector, drinking and bathing for the domestic sector, water for the industrial operation and recreation are the major ones.

River is played very important role in emerged of the town as very essential resources water for the urban area, supply of infrastructure facilities easier than hill slopes. Historically the ancient city was emerged on low land of the river basin such as Euphrates, Nile etc. Like wise the first capital city of Anuradhapura in Sri Lanka was estab ished on the Malwatu Oya stream. Presently most of the cities emerged on river with several sub systems of other resource. As a result of unplanned expansion of the urban settlements on river basins faced sever problems of down stream and upper catchment development.

This paper attempts to introduce the concepts and major issues of the rivers and proposed to guidelines for planned development on river basin in order to minimize environment pollution and adverse implication of haphazard developmen on hilly slopes. It contributes the planned urbanization on river basins and strengthening the national economy and prosperity as a sub system of whole systems. 